\title{
Influence of composting and thermal processing on the survival of microbial pathogens and nutritional status of Nigeria sewage sludge
}

\author{
Kayode Fatunla ${ }^{1,3} \cdot$ Edu Inam $^{2,3} \cdot$ Joseph Essien $^{1,3} \cdot$ Emmanuel Dan $^{2,3}$. \\ Akanimo Odon ${ }^{5} \cdot$ Suil Kang $^{5} \cdot$ Kirk T. Semple $^{4}$
}

Received: 6 January 2017 / Accepted: 16 September 2017/Published online: 21 September 2017

(c) The Author(s) 2017. This article is an open access publication

\begin{abstract}
Purpose Sewage sludge samples from a water treatment plant in Nigeria were subjected to an in-vessel composting (using sawdust as a bulking agent) and thermal sludge processing to improve its quality for agricultural applications. Methods Treated samples were analyzed for physicochemical and microbiological properties using standard analytical and aerobic culture protocols.

Results Microbiological analysis of the initial fresh mixture (sewage sludge/sawdust) showed that the total heterotrophic bacteria was $1.17 \times 10^{6} \mathrm{CFU} / g$ of fresh compost, coliforms $4.7 \times 10^{4} \mathrm{CFU} / \mathrm{g}, \quad$ Salmonella sp., and Shigella sp. $7.3 \times 10^{4} \mathrm{CFU} / \mathrm{g}$, yeasts and moulds $9.0 \times 10^{4} \mathrm{CFU} / \mathrm{g}$. These values were significantly $(p=0.05)$ reduced after 40 days of in-vessel composting to $4.3 \times 10^{4} \mathrm{CFU} / \mathrm{g}$ for total heterotrophic bacteria, $7.4 \times 10^{2} \mathrm{CFU} / \mathrm{g}$ for coliforms, while yeasts and moulds, Salmonella and Shigella sp. were not detected in the final compost. The results of the
\end{abstract}

Kayode Fatunla

opeyemifatunla@uniuyo.edu.ng

1 Department of Microbiology, University of Uyo, Uyo, Nigeria

2 Department of Chemistry, University of Uyo, Uyo, Nigeria

3 International Centre for Energy and Environmental Sustainability Research (ICEESR), University of Uyo, Uyo, Nigeria

4 Lancaster Environment Centre, Lancaster University, Lancaster, UK

5 International Environmental Research Centre (IERC), Gwangiu Institute of Science and Technology (GIST), Gwangiu 500-712, South Korea physicochemistry revealed variation in $\mathrm{pH}$, temperature, and nutrients status of treated sludge.

Conclusion Salmonella sp., Staphylococcus aureus, and Shigella sp. were eliminated, while a 2-log reduction in coliform counts occurred after 40 days of composting. Composting had a better processing impact by increasing the ash as well as reducing the carbon/nitrogen ratio of treated sludge, while thermal processing improved the sulfate and phosphate components of treated sludge. The treated sludge (biosolids) met the permissible limits of microbiological and nutritional standards recommended by US EPA for land application of sludge and could, therefore, be used as a biofertilizer, soil conditioner and also for land reclamation.

Keywords Sludge $\cdot$ Composting $\cdot$ Sawdust $\cdot$ Biosolid $\cdot$ Soil conditioner

\section{Introduction}

The problem of waste generation, control and management has become a well-known phenomenon in a typical Nigerian city, it has been estimated that municipal solid waste generated in a typical Nigerian city was estimated to be around 4 million tonnes (Kofoworola 2007). With the recent establishment of Bwari Lower Usuma Dam Water Treatment Plant, a major wastewater treatment plant with a capacity of 30,000 cubic meter of water per hour, this estimation is expected to triple in few years to come with addition of several tonnes of sewage sludge.

The use of waste to generate other useful by-products is recently common due to the advent of new technologies for the conversion of wastes of any form into valuable products. However, sludge waste is another kind of waste which 
applications are rarely exploited, especially in developing countries. It is defined as the residue generated from the treatment of wastewater (Smith et al. 2009). Sewage sludge is the solid, semi-solid, or liquid residue generated from the treatment of domestic sewage. It is very rich in nutrients (nitrogen and phosphorus), organic matter and some trace elements needed for plant growth. However, sewage sludge is more than often discarded in landfills, resulting in nuisance and possible environmental contamination. Because of the legislation restricting the disposal of sewage sludge by incineration, fresh water dilution, and ocean dumping, many municipalities are considering land application methods for disposing of their sludge. Recently, attention of researchers had shifted to composting of nutrient-rich sewage sludge for agricultural and horticultural purposes. Sewage sludge contains nitrogen and phosphorous, present as a result of nitrification and denitrification phases during wastewater treatment process. Since these elements are essential for plant growth, their presence in sludge gives it unique fertilizing benefits (Fytili and Zabaniotou 2008). Composting sludge and sawdust together results in stabilized product as a consequence of the actions of aerobic thermophilic microorganisms, which utilize a part of the organic rich compost for their metabolism. During this decomposition, temperature as high as $55-70{ }^{\circ} \mathrm{C}$, are generated which leads to the destruction of microbial pathogens, especially the Enterobacteriaceae. The end result is a humus-like material which can now be served as a source of nutrients to plant. It is essentially free of human enteric pathogens and offensive odors (Hornick et al. 1984; Nilsson and Dahlström 2005; Andreoli et al. 2007).

It has been reported that stabilized sewage sludge utilized properly on land can make a positive impact in agriculture, forestry, horticulture and city development as well as land reclamation (Wang 1997; Forste 1997). The main obstacles of sewage sludge application on land are pollutants such as heavy metals, organic pollutants, and pathogens concentrated in sewage sludge during wastewater treatment (Wang 1997). This later components of sewage sludge (such as heavy metals) may be harmful to humans should they find their way into the food chain (Fytili and Zabaniotou 2008). The major pathogens of concern in sewage sludge include bacteria such as Salmonella sp. responsible for typhoid fever and food poisoning, Shigella sp. (bacillary dysentery), Yersinia sp. (acute gastroenteritis), Vibrio cholera (cholera), Campylobacter jejuni (gastroenteritis) and the pathogenic strains of Escherichia coli (gastroenteritis). Enteric and Enteroviruses (hepatitis a virus, norwalk and norwalk-like viruses), Rotaviruses, Poliovirus, Coxsackieviruses (meningitis, pneumonia, cold-like symptoms). Protozoans such as Cryptosporidium (gastroenteritis), Entamoeba histolytica (acute enteritis), Giardia lamblia (giardiasis), Balantidium coli (diarrhea and dysentry), Toxoplasma gondii (toxoplasmosis) and Helminth worms such as Ascaris lumbricoides (digestive and nutritional disturbances), Trichuris trichuria (abdominal pain), Taenia saginata (nervousness, insomnia and anorexia), Taenia solium (abdominal pain). The route of exposure to these pathogens may be during direct contact with sewage sludge or indirectly by consuming drinking water or food contaminated by these pathogens. Transport of sewage sludge pathogens from site of application to humans are mostly through insects, birds, rodents and farm workers (Kowal 1985; US EPA 2017).

Composting technologies have been developed to convert wastes into compost and organo-mineral fertilizers (Egbewumi et al. 1997; Sridhar and Adeoye 2003). The organo-mineral fertilizers produced from composting is a good soil conditioner and is ideal for Nigerian soil for good crop yields. Nigeria like other countries of the world faces challenges with respect to food security. It is documented that governments in sub-Saharan Africa spend as much as 1 billion US dollars each year in fertilizer subsidy (Jayne et al. 2013). Therefore, locally made alternatives and/or supplement to inorganic fertilizers would prove efficient in a bid to secure Nigeria's food insecurity and agricultural sustainability (Ogunwole and Ogunleye 2005). It is, therefore, necessary to investigate the processing of waste streams particularly sludge from water treatment facilities across the country which can then be used as amendment to soils. The amended product will offer a safe and sustainable source of nutrients for agricultural practice, thereby reducing pressure on natural resources and to address some of the challenges of waste management in Nigeria.

In this study, we evaluate the influence of composting and thermal sludge processing treatments on the survival of pathogens and the nutritional status of sludge meant for agricultural applications.

\section{Materials and methods}

\section{Study site}

Sludge samples were obtained from Lower Usuma Dam Water Treatment Plant (LUDWTP) located in Abuja, Nigeria between latitude $9^{\circ} 25^{\prime} 12^{\prime \prime} \mathrm{N}$ and longitude $7^{\circ} 45^{\prime} 16^{\prime \prime} \mathrm{E}$. It has a capacity to process 120 million liters of waste water and provide Abuja and its neighboring areas with the same amount of clean drinking water per day.

\section{Experimental setup/procedure}

\section{Sludge composting}

The sludge sample was subjected to composting using the method described by Andreoli et al. (2007) and Ahmed 
et al. (2007). In this method, $35 \mathrm{~kg}$ of sludge was mixed with $47 \mathrm{~kg}$ of sawdust in a 0.8-m-high and 0.5-m-wide vessel on a composting in-vessel type (Andreoli et al. 2007). The mixture was prepared such that composting parameters, i.e., $57 \%$ humidity and a $\mathrm{C} / \mathrm{N}$ ratio of about 30 were optimized. To maintain aerobic condition during composting, the mixture was turned manually every 3 days. The composting process lasted for 40 days and substrate temperature was taken daily at different points inside the vessel. The compost was air-dried and bagged.

\section{Thermal sludge treatment}

The sludge sample was heat treated by keeping the samples in the oven at $180{ }^{\circ} \mathrm{C}$ for $30 \mathrm{~min}$. Treated samples were allowed to cool and thereafter taken for physicochemical and microbiological analyses.

\section{Physicochemical and nutrient content analysis of treated sludge}

Biosolid (treated sludge samples) were taken systematically before composting $\left(t_{0}\right)$, and after composting $\left(t_{40}\right)$ for physicochemical and nutrient content analysis using standard analytical protocols (APHA 2005). The parameters analyzed were temperature, $\mathrm{pH}$, dry mass, organic carbon, total nitrogen, carbon-nitrogen ratio, sulfate, phosphate, nitrate and ammonium content.

\section{Microbiological analysis of treated sludge}

Samples were taken in triplicates before composting $\left(t_{0}\right)$, at day 5 of composting $\left(t_{5}\right)$, and at $t_{10}, t_{15}, t_{20}, t_{25}, t_{30}, t_{35}$ and $t_{40}$, respectively, for microbiological analysis. A sub-sample of $10 \mathrm{~g}$ of biosolid was added to $90 \mathrm{ml}$ of sterile phosphate-buffered saline (PBS) solution aseptically. As described by Cappucino and Sherman (2002) $10^{-1}-10^{-3}$ dilutions were made using sterile PBS solutions. Total heterotrophic bacteria, fecal coliform, Salmonella and Shigella spp as well as the yeast and mold counts of the samples were determined. The number of heterotrophic bacteria was determined on Nutrient Agar (Oxoid, UK) by incubating plates at $37{ }^{\circ} \mathrm{C}$ for $48 \mathrm{~h}$. Yeast and mold fungi were determined on Sabouraud dextrose agar at $25{ }^{\circ} \mathrm{C}$ for 5 days. Salmonella sp. was determined on Selenite F medium and Salmonella Shigella agar after 18-24 h at $36{ }^{\circ} \mathrm{C}$. Total coliform and fecal coliform were determined with MacConkey agar and Eosin-Methylene Blue agar, respectively, after incubation at $37^{\circ} \mathrm{C}$ for $24 \mathrm{~h}$. Viable cells were enumerated using stuart colony scientific counter (UK).

\section{Statistical analysis}

The data were subjected to descriptive statistics and analysis of variance (ANOVA). The LSD and Levene's homogeneity of variance were also investigated using IBM SPSS windows version 20 package (IBM Corp, USA), and the significance of the treatment means were tested at $p \leq 0.05$.

\section{Results and discussion}

\section{Basic physical and chemical parameters of the composted mixtures}

Comparison of the initial parameters of all studied mixtures is presented in Table 1. C:N ratio of compost was 30.1, which was dependent on the ratio of sewage sludge (rich in nitrogen) with sawdust (rich in carbon) (Fig. 1).

\section{Effects of composting on sludge physicochemistry and microbiological properties}

The physicochemical properties of the mixed raw materials obtained at different times of composting are presented in Figs. 2 and 3. The $\mathrm{pH}$ values were within the optimal range (pH 7.2-8.11) for the proliferation of bacteria, in the first 5 days of composting and reached a plateau over the next 10 days. There was a slight acidification of the compost (a decrease from 9.1 to 7.34 ) between day 20 and 40. Two phases of the composting process were recorded: stabilization phase (about 15 days), where temperature increased to $65^{\circ} \mathrm{C}$ and $\mathrm{pH}$ increased to 8.35; and maturation phase (about 25 days) characterized by a sharp decrease in temperature from 65 to $35^{\circ} \mathrm{C}$ and finally to $30{ }^{\circ} \mathrm{C}$ on the 40th day. These findings are in accordance with those of Czekala et al. (2016) and Egbuna et al. (2016). However, the physicochemistry and nutrient profile of compost on the 40th day revealed a decrease in the organic matter content from 38.65 to $22.16 \%$, while the $\mathrm{C} / \mathrm{N}$ ratio reduced from 30.1 to 20.12 in treated compost (Figs. 4 and 5). The results also showed a reduction in

Table 1 Physicochemistry of raw materials used for composting

\begin{tabular}{lcl}
\hline Parameters & Sewage sludge & Saw dust \\
\hline Dry mass (\%) & 2.85 & 72.5 \\
pH & 7.2 & - \\
Organic carbon (\%) & 47.5 & 51.5 \\
Total nitrogen (\%) & 1.98 & 0.15 \\
Carbon to nitrogen ratio (C:N) & 10.93 & 343.3 \\
\hline
\end{tabular}


Fig. 1 Microbial load of raw materials used for composting. Key: THBC total heterotrophic bacterial count, TYMC total yeast and mould count, $T C C$ total coliform count, $S C$

Staphylococcal count, $P C$ pseudomonad count, SSC

Salmonella shigella count

Fig. $2 \mathrm{pH}$ changes during composting

Fig. 3 Mean temperature changes during composting
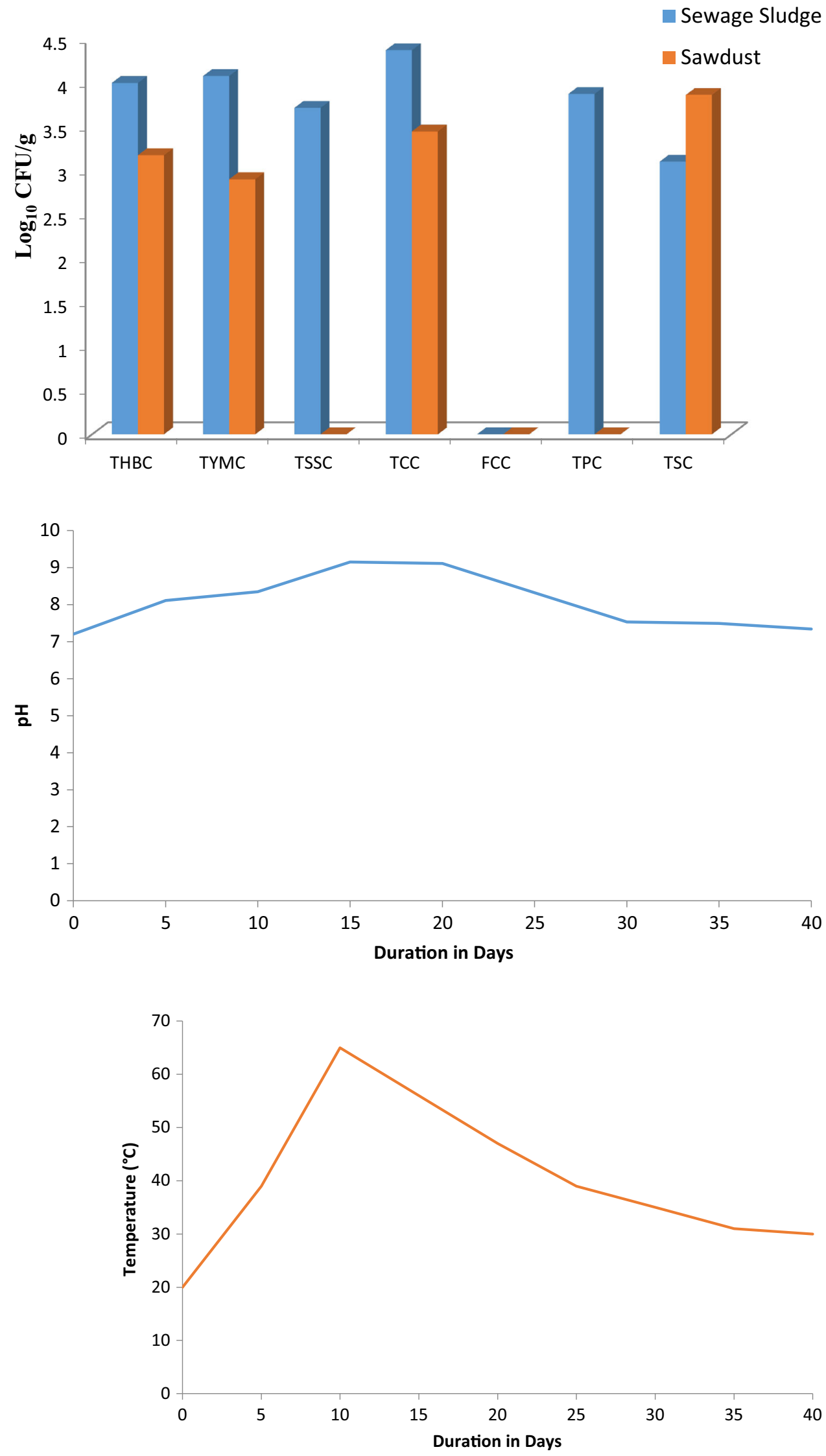
Fig. 4 Physicochemical properties of sludge after 40 days of composting

Fig. 5 Nutrient profile of sludge after 40 days of composting
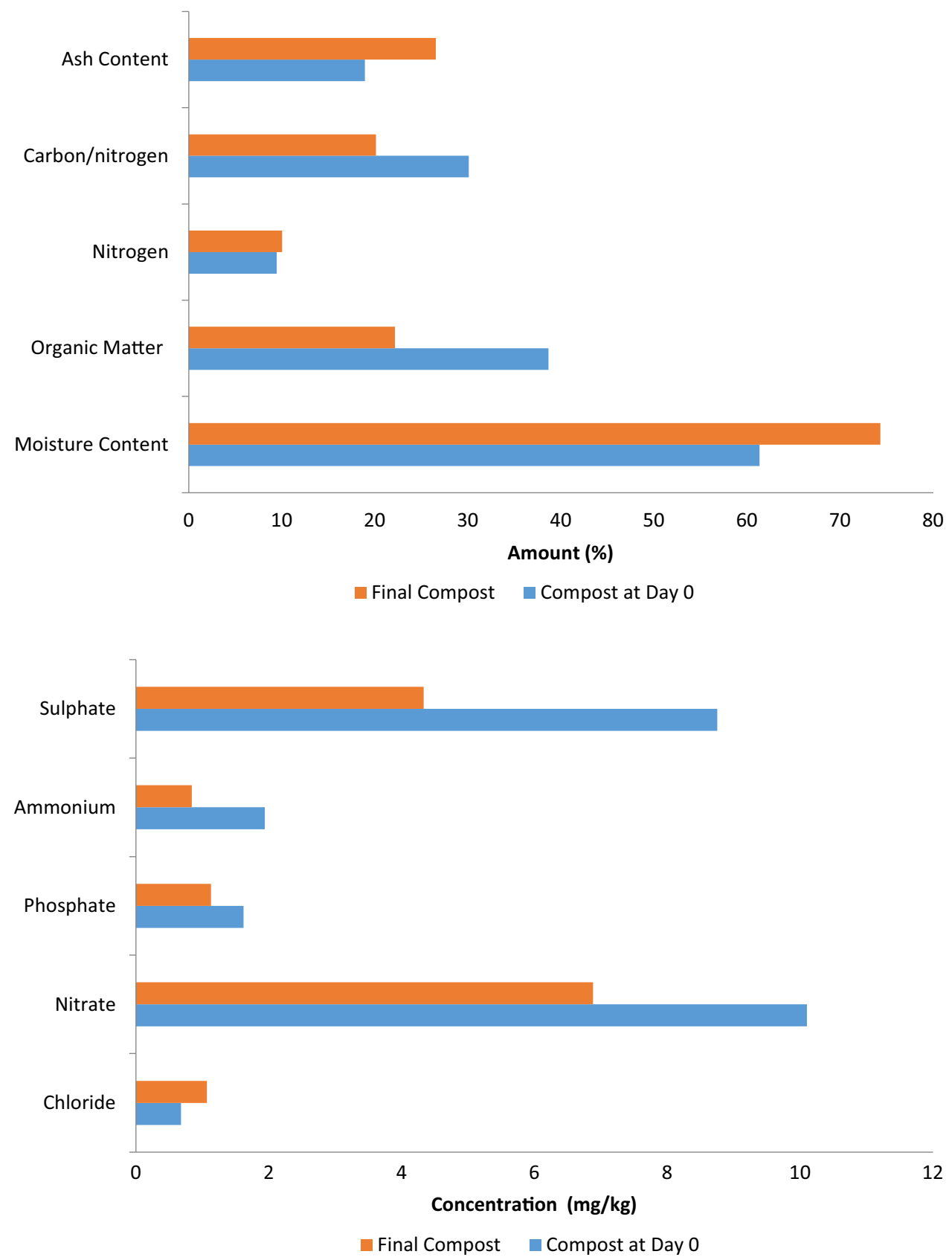

nitrate $(10.1-6.88 \mathrm{mg} / \mathrm{kg})$, phosphate $(1.62-1.13 \mathrm{mg} / \mathrm{kg})$, ammonium $(1.94-0.84 \mathrm{mg} / \mathrm{kg}$ ) and sulfate $(8.75-4.33 \mathrm{mg} /$ $\mathrm{kg})$ contents.

Changes in the physicochemical parameters and nutrient content of composted sludge could be attributed to ongoing microbial activities during the process. The change in the $\mathrm{C} / \mathrm{N}$ ratio from 30.1 to 20.12 and the amount of ash present in the final compost is indicative of microbial degradation of organic matter and stabilization processes occurring during composting. Decomposition of organic matter led to the production of stable humic compounds which can interact with metal ions, buffer $\mathrm{pH}$, and serve as source of nutrients that are utilizable for plants. Soumare et al. (2002) have reported that reduction in substrate carbon occurring as a result of $\mathrm{CO}_{2}$ loss led to the increase in total nitrogen during composting since decomposition of the organic matter which is chemically bound with nitrogen occurred. The decrease in the amount of inorganic nitrogen, $\mathrm{N}-\mathrm{NH}_{4}$ and $\mathrm{N}-\mathrm{NO}_{3}$ was as a result of the action of bacteria that can degrade proteins and their conversion to stable organic forms such as amide and heterocyclic nitrogen. These findings were corroborated by Egbuna et al. (2016). Electrical conductivity of the final compost was below the salinity limit value of $3 \mathrm{~ms} / \mathrm{cm}$ for compost to be used as 
organic fertilizer (Soumare et al. 2003). Available and total phosphorous, nitrogen, sulfur, as well as carbon make the compost good for use as a mineral fertilizer (Soumare et al. 2003). Compost application will, therefore, lead to an increase in the levels of stable organic nitrogen and humic carbon and this will invariably improve mineral elements necessary for plant growth.

The microbiological analysis of the raw sewage sludge and sawdust used for the composting is shown in Fig. 1. The initial mixture (sewage sludge/sawdust) harbored $1.17 \times 10^{6} \mathrm{CFU} / \mathrm{g}$ of heterotrophic bacteria, $4.7 \times 10^{4}$ of coliform bacteria, $7.3 \times 10^{4} \mathrm{CFU} / \mathrm{g}$ of Salmonella and Shigella sp., $9.0 \times 10^{4} \mathrm{CFU} / \mathrm{g}$ of yeasts and moulds in fresh compost (Table 1). Reduction in microbial density was significant $(p=0.05)$ after 40 days of composting. $4.3 \times 10^{4} \mathrm{CFU} / \mathrm{g}$ and $7.4 \times 10^{2} \mathrm{CFU} / \mathrm{g}$ for heterotrophic bacteria and coliforms, respectively, while viable cells of Salmonella and Shigella sp., yeasts and moulds, were not detected in the final compost after 40 days (Fig. 6). The comparative status of microbial contaminants in the fresh and treated (biosolid) sludge samples is presented in Fig. 7. The above results have shown that composting had a positive influence on the microbial quality of sludge. However, its effect varied with the diverse microbial groups, their activities which are often affected by exhaustion of nutrients, $\mathrm{pH}$ and temperature changes. In this study, temperature was at its peak $\left(65^{\circ} \mathrm{C}\right.$, thermogenic phase) at day 10 of composting. Czekala et al. (2017) recorded similar findings. Maintaining the temperature at $60{ }^{\circ} \mathrm{C}$ from the beginning of composting to day 15 resulted in a significant elimination of total aerobic heterotrophs, yeasts and moulds as well as the pathogenic group of Salmonella and Shigella. At this temperature, elimination of pathogens only requires few days to achieve (Dumontet et al. 1999). Although aerobic bacteria, mostly Bacillus species, are often active between 60 and $65^{\circ} \mathrm{C}$, composting temperatures should not exceed $75{ }^{\circ} \mathrm{C}$, as this will lead to irreversible denaturation of
Fig. 6 Microbial population dynamics during composting. Key: $T H B C$ total heterotrophic bacterial count, $T Y M C$ total yeast and mould count, TCC total coliform count, $F C C$ fecal coliform count, TSC total Staphylococcal count, TPC total pseudomonad count, TSSC total Salmonella shigella count

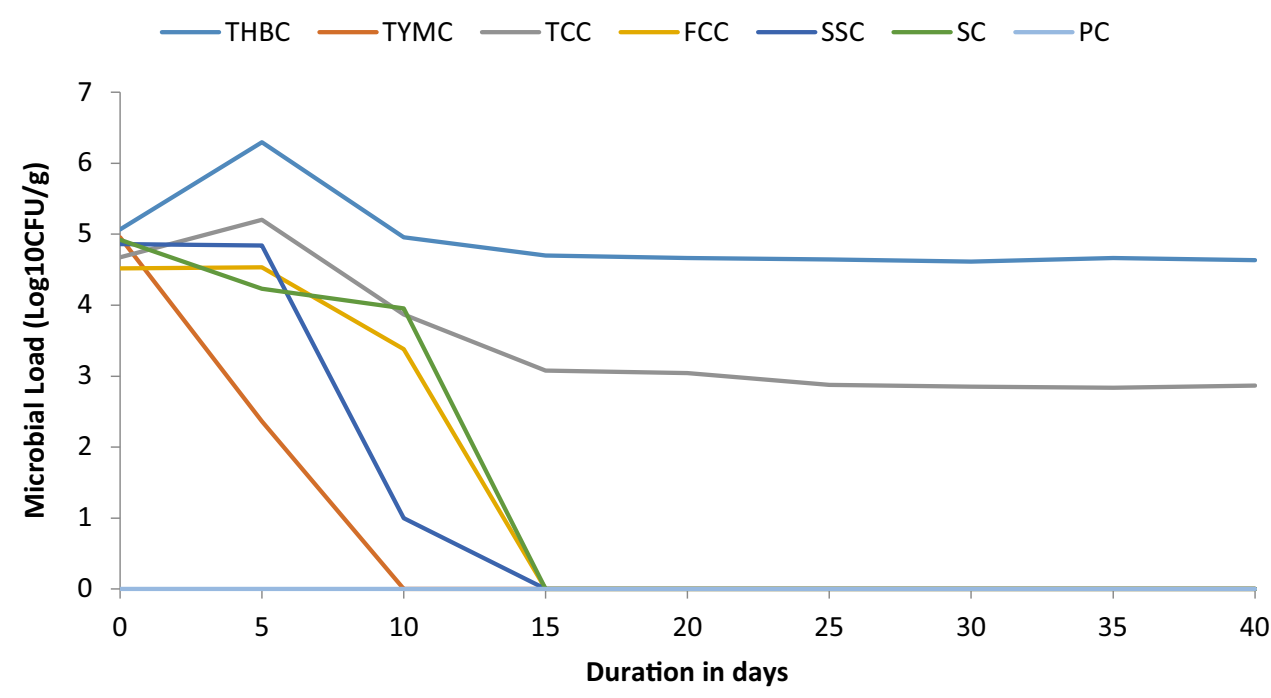

Fig. 7 Comparative microbiological status of the sludge and biosolid derived from composting. Key: $T H B C$ total heterotrophic bacterial count, TYMC total yeast and mould count, TCC total coliform count, $F C C$ fecal coliform count, TSC total Staphylococcal count, TPC total pseudomonad count, TSSC total Salmonella shigella count

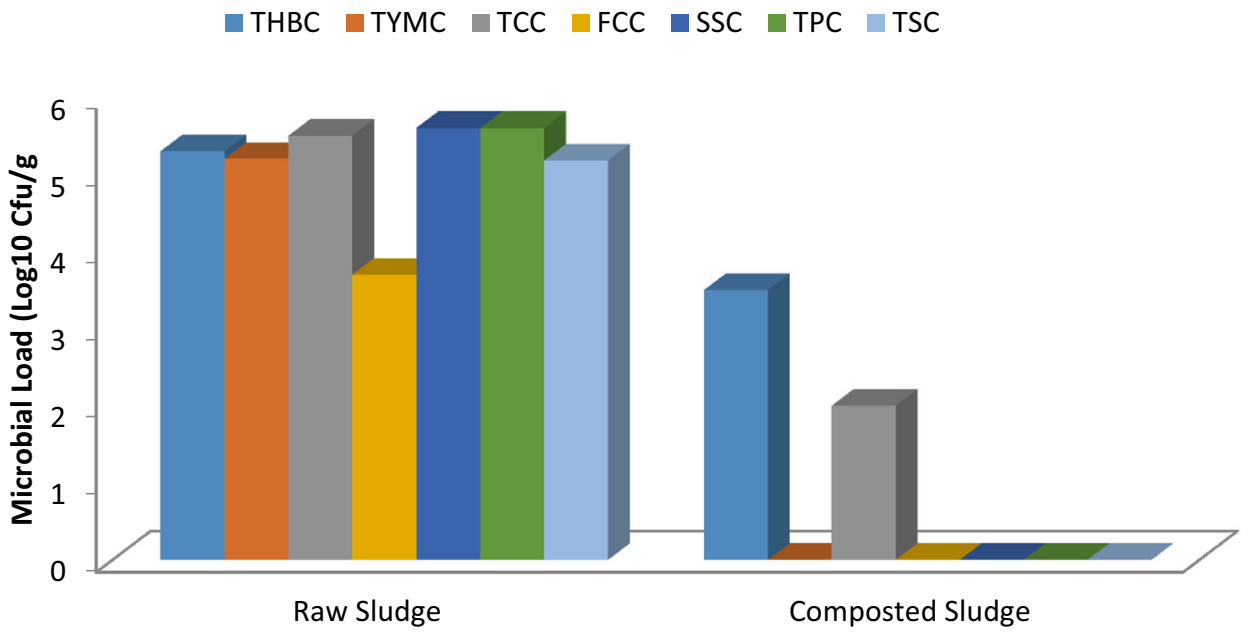


bacterial enzymes (Tuomela et al. 2000). This intense microbial activity resulted in a significant transformation of the composting mixture. The changes in the number of heterotrophic bacteria (Fig. 6) during composting is an indication of the variation that exists between temperature and cell proliferation i.e., as temperature increases the number of cells decreases and vice versa, a reflection of the effectiveness of the process. Miyatake and Iwabuchi (2006) suggested that changes in temperature during composting have an effect on changes in microbial activities, diversity and distribution, and thereby on the effectiveness of composting. Similarly as in this study, an increase in the number of heterotrophic bacteria was followed by a decrease in the rate at which cells are proliferated which in turn led to an increase in temperature as previously reported by Hassen et al. (2014). Further analysis, however, revealed a decrease in the number of heterotrophs in spite of a further decrease in temperature. This is probably due to the depletion of organic matters that can decompose easily, or proliferation of the antibiotic producing Actinomycetes from which the compost got its earthy odor. Similar result was recorded for fungi and increase in temperature of compost was mostly the main factor that led to a decrease in fungal density. Previous study by Hassen et al. (2014) has shown that decrease in fungal density is not necessarily caused by temperature increase alone during composting as other factors such as antagonism, the presence of antibiotics and $\mathrm{pH}$ increase were also listed as important factors. Similar findings are reported in this study.

Salmonella and Shigella genera were not detected in the final compost (Fig. 7). The absence of these pathogens in the final compost was mostly as a result of temperature rise above $60{ }^{\circ} \mathrm{C}$ between the 5th and 10th day of composting and it is usually an indication of the efficacy of the process. Composting of sewage caused a significant $(p=0.05)$ reduction in the number of enteric bacteria in the biosolid. Although coliforms were not completely eliminated, their levels fell within acceptable limits of $<100 \mathrm{CFU} / 25 \mathrm{~g}$ of coliforms in the final compost meant for land application (US EPA 2017).

\section{Effects of thermal processing on sludge physicochemistry and microbiological properties}

The physicochemical properties and level of nutrients in thermally processed sludge are presented in Figs. 8 and 9, respectively. The results revealed increase in the organic
Fig. 8 Physicochemical properties of thermally processed sludge $\square$ THBC TYMC $\square$ TCC FCC $\square$ SSC $\square$ TPC $\square$ TSC

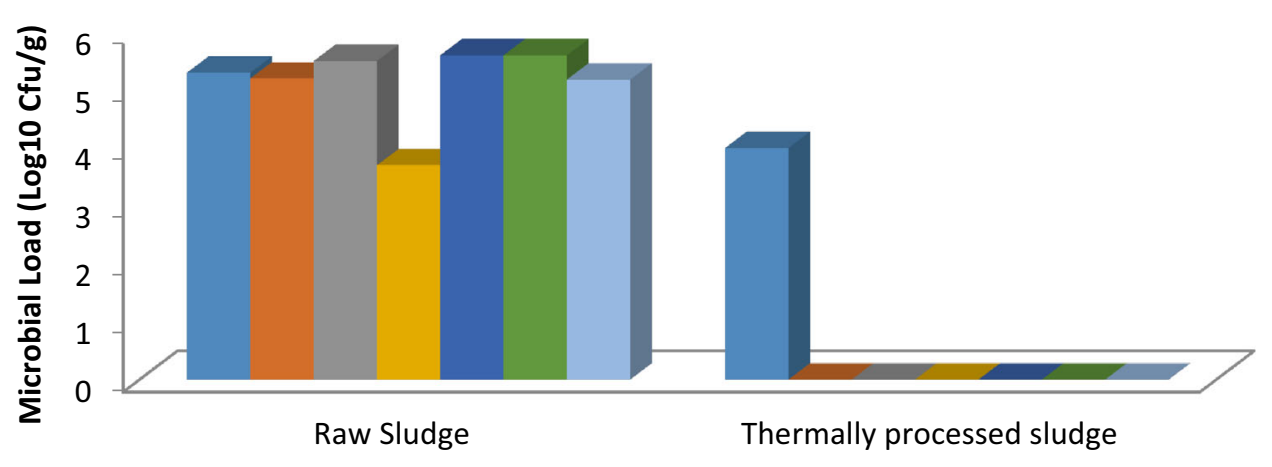

Fig. 9 Nutrient profile of thermally processed sludge

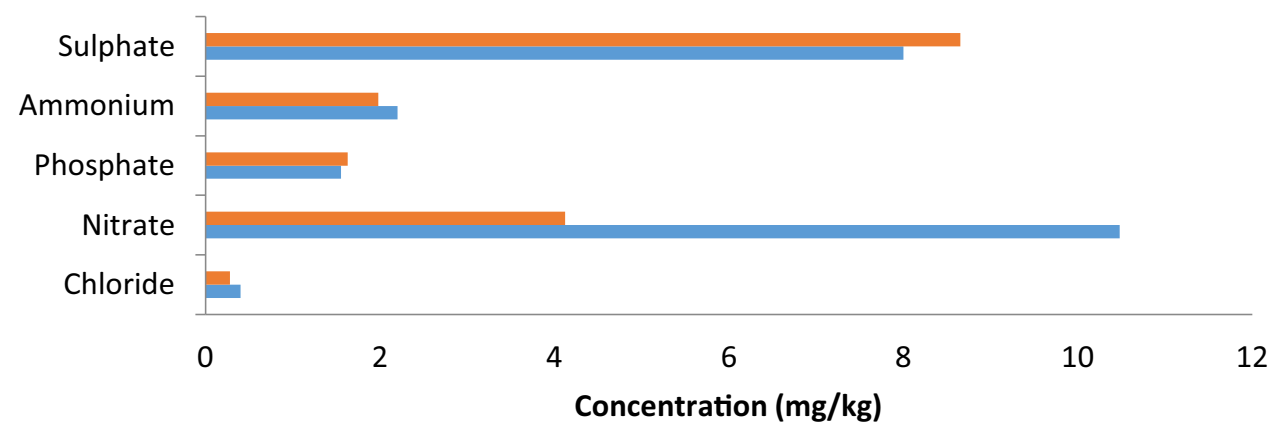

Thermally processed sludge $\quad$ Raw Sludge 
Fig. 10 Comparative microbiological status of raw sludge and thermally processed sludge $\square$ THBC $\square$ TYMC $\square$ TCC $\square C C \square$ SSC $\square$ TPC $\square$ TSC

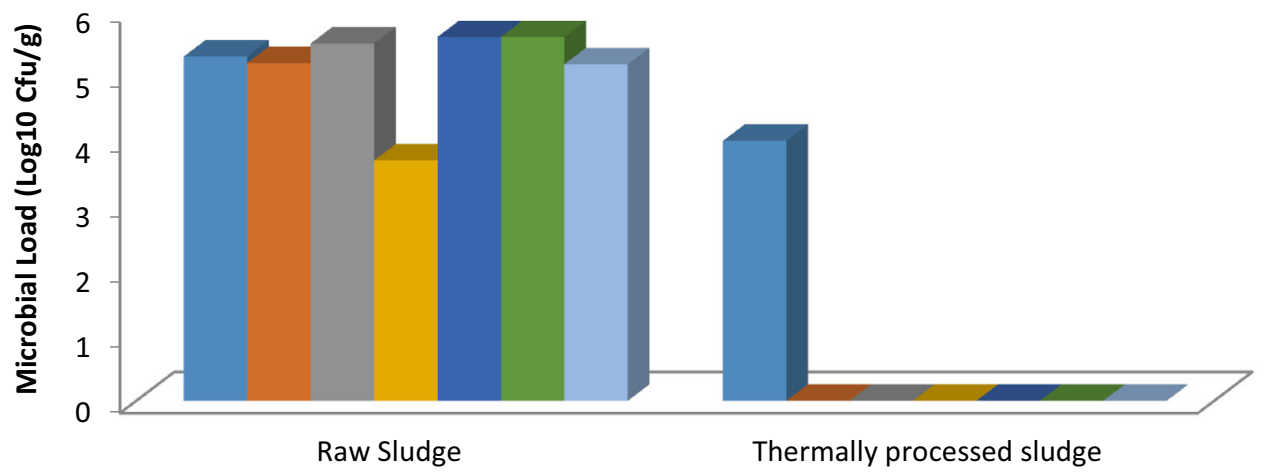

matter content from $91.7 \%$ in raw sludge to $94.5 \%$ in heat-treated sludge, and also a significant increase in the $\mathrm{C} / \mathrm{N}$ ratio from 18.56 to 36.65 . The density of heterotrophic bacteria was significantly $(2 \log$ unit at $p=0.05$ ) reduced after $30 \mathrm{~min}$ of oven drying at $180{ }^{\circ} \mathrm{C}$, while no viable cells of coliforms, yeasts and moulds, Salmonella and Shigella sp. were detected in the thermally processed sludge (Fig. 10). The changes in the physicochemical parameters and nutrient content (Figs. 8 and 9) of the thermally processed sludge could be attributed to the effect of heat. There was a noticeable reduction in the amount of chloride, nitrate, and ammonium, while a slight increase was recorded for phosphate and sulfate. Volatilization of elements when exposed to heat is not a new phenomenon (Nilsson and Dahlström 2005). Some elements especially nitrogen are given off as gas when their inorganic form is exposed to high temperature. Although the level of these nutrients in the thermally processed sludge was lower than that of the composted sludge, they were still within limit and could be applied on land especially those deficient in phosphorus and sulfur.

The effect of high temperature on microorganism is severe (Andreoli et al. 2007). The microbial group analyzed in this study were completely eliminated when exposed to the treatment temperature of $180{ }^{\circ} \mathrm{C}$ for $30 \mathrm{~min}$, except the total heterotrophs, whose density was reduced only by a log unit (Fig. 10). The findings in this study have revealed that Bacillus represents the bulk of heterotrophs in sludge. Bacillus species are spore formers and can, therefore, survive harsh environmental conditions especially heat, as was the case in this study. Bacillus species amongst other heterotrophs are not of public health concern in treated sludge (US EPA 2017; Nilsson and Dahlström 2005; Andreoli et al. 2007). Their presence could help in mineralization of elements (especially phosphate solubilization) essential for plant growth and development.

\section{Efficacy of the treatment methods}

Analysis of the efficacy of the sludge treatment methods showed that composting had a better processing impact on the nutrient attributes of the sludge by increasing the ash and moisture content of sludge, sustaining the nitrogen content and reducing the carbon/nitrogen ratio (Fig. 11). It also had a better influence on the nitrate and chloride contents of the sludge, while thermal processing improves the sulfate and phosphate components of treated sludge (Fig. 12). The results also showed that both treatments were positive against potential microbial pathogen and in addition, processing by composting had a more acceptable effect on the heterotrophic properties of the derived biosolid (Fig. 13). The results have also shown that although thermal processing increases the concentrations of plants, essential element such as phosphate in biosolid, treatment by composting did not only improve the microbiological quality of treated sludge but also increased the ash and moisture content of sludge, sustained the nitrogen content and reduced the carbon/nitrogen ratio of the biosolid. These findings are in consonance with studies by Ahmed et al. (2007). Treatment by composting also had a better influence on the nitrate and chloride contents of the treated sludge. The findings suggest that formulations of biosolids derived from both treatment processes can be harnessed for production of nutrient-rich soil amendment or biofertilizer.

\section{Conclusion}

The research findings have shown that although Nigeria sewage sludge is rich in plant nutrients, it habours plethora of microorganisms including pathogens and microbes with beneficial attributes. Its use as soil conditioner can only be promoted if treated. In this study, composting and thermal processing were successfully used to eliminate pathogenic 
Fig. 11 Effect of composting and thermal treatment on the physicochemical properties of sewage sludge

Fig. 12 Effect of composting and thermal treatment on the nutrient profile of sewage sludge

Fig. 13 Effect of compost and thermal treatment on the microbial load in sewage sludge. Key: $T H B C$ total heterotrophic bacterial count, $T Y M C$ total yeast and mould count, TCC total coliform count, FCC fecal coliform count, TSC total Staphylococcal count, TPC total pseudomonad count, TSSC total Salmonella shigella count
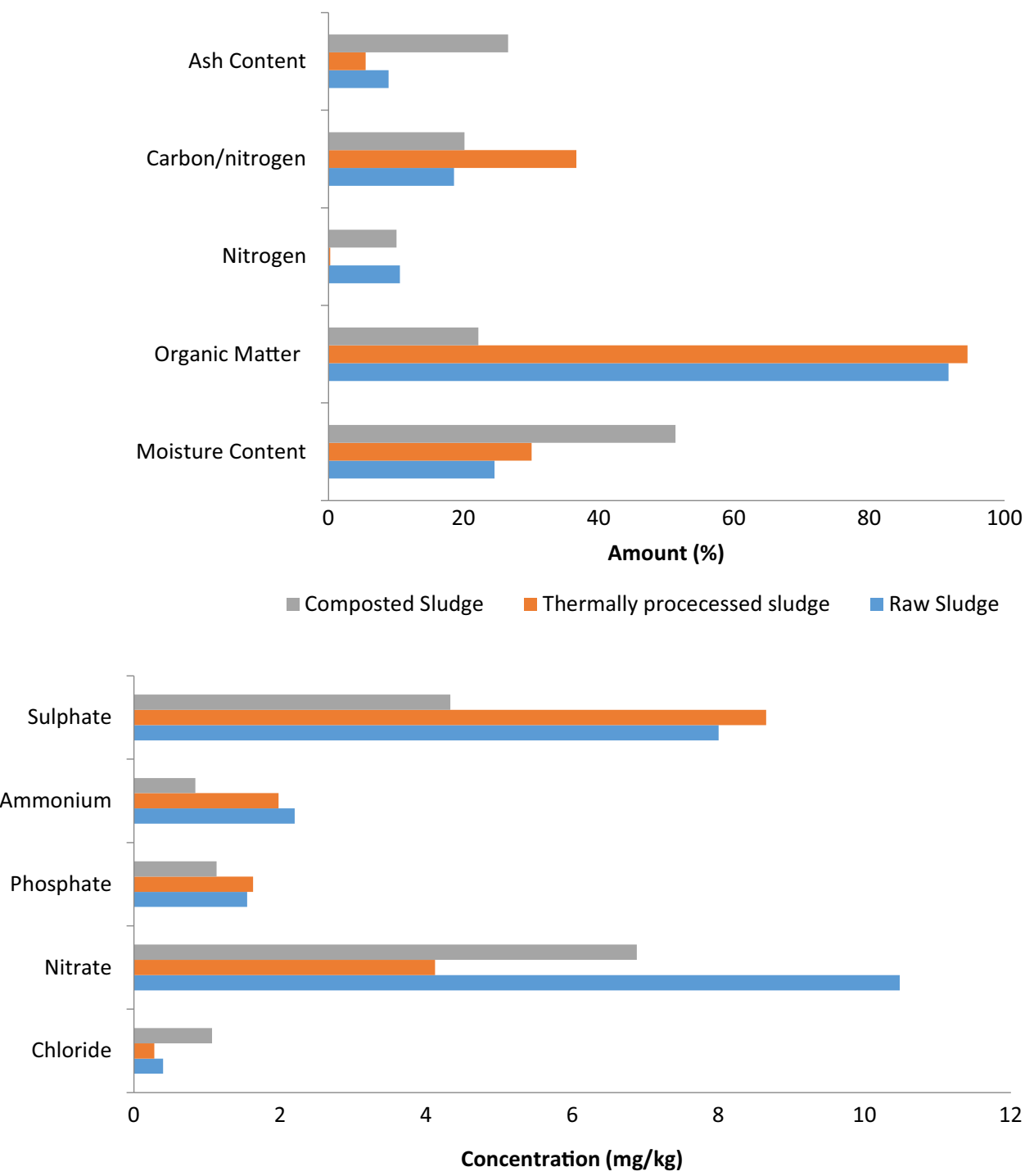

Composted Sludge $\quad$ Thermally processed sludge Raw Sludge

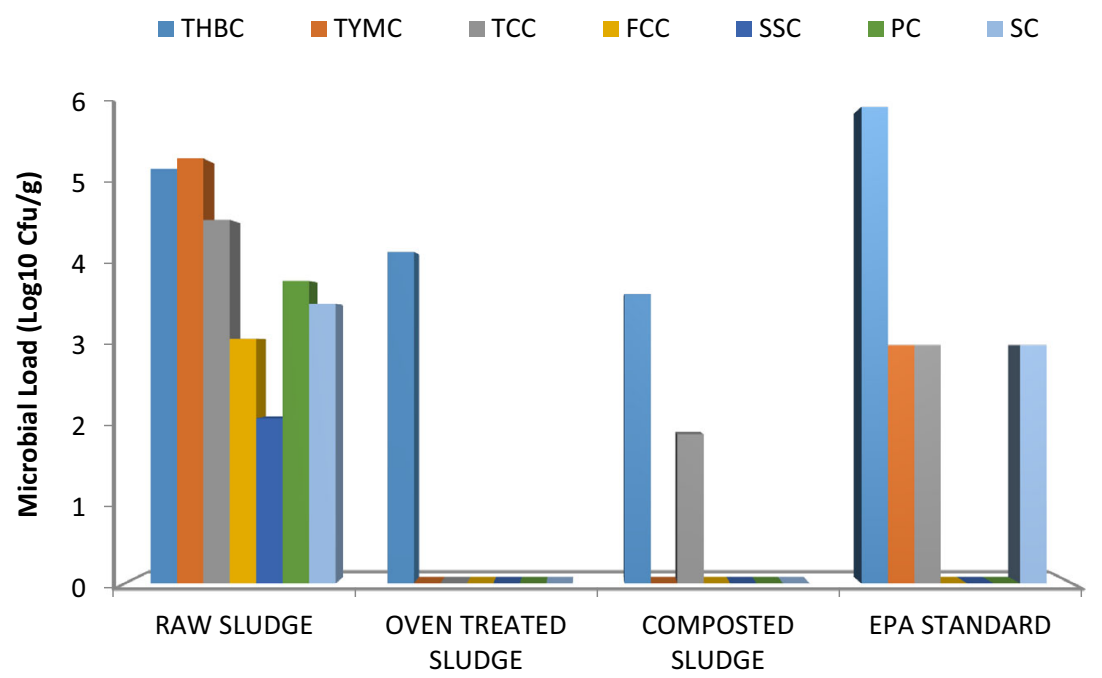


microorganisms especially Salmonella, Shigella and Staphylococcus species, whose presence in treated sludge represents a public health concern and may render it nonapplicable on agricultural land. Composting of Nigeria sludge destroys the microbial pathogens and improves its plant nutrient status to levels that may be used in agriculture as a soil conditioner to restore or maintain the humus layer or as a bio-fertilizer.

Acknowledgements Funding support for this study was provided by the Ministry of Science and Technology, South Korea through the Institute of Science and Technology for Sustainability (UNU and GIST Joint Programme).

\section{Compliance with ethical standards}

Conflict of interest The authors declare that they have no conflict of interest.

Open Access This article is distributed under the terms of the Creative Commons Attribution 4.0 International License (http://crea tivecommons.org/licenses/by/4.0/), which permits unrestricted use, distribution, and reproduction in any medium, provided you give appropriate credit to the original author(s) and the source, provide a link to the Creative Commons license, and indicate if changes were made.

\section{References}

Ahmed M, Idris A, Omar SR (2007) Physicochemical characterization of compost of the industrial tannery sludge. J Eng Sci Technol 2(1):81-94

American Public Health Association (2005) Standard methods for examination of water and wastewater, 14th edn. American Public Health Association, New York

Andreoli CV, Sperling M, Fernandes F (2007) Sludge treatment and disposal, 1st edn. IWA, London, pp 73-77

Cappuccino JG, Sherman N (2002) Techniques for isolation of pure culture. In: Microbiology: a laboratory manual, 6th edn. Pearson Education, Inc., Singapore, p 544

Czekała W, Dach J, Janczak D, Smurzyńska A, Kwiatkowska A, Kozłowski K (2016) Influence of maize straw content with sewage sludge on composting process. J Water L Dev 30:43-49. doi:10.1515/jwld-2016-0020

Czekała W, Dach J, Dong R, Janczak D, Malińska K, Jóźwiakowski K, Smurzyńska A, Cieślik M (2017) Composting potential of the solid fraction of digested pulp produced by a biogas plant. Biosyst Eng 160:25-29

Dumontet S, Dinel H, Baloda SB (1999) Pathogen reduction in sewage sludge by composting and other biological treatment. Biol Agric Hortic 16:409-430. doi:10.1080/01448765.1999. 9755243

Egbewumi OO, Sridhar MKC, Asuzu MC (1997) Composting through community action: a rural experience in Nigeria. J Appropr Technol 23:34-35

Egbuna SO, Asadu CO, Onoh MI (2016) Production of biofertilizer by composting sawdust sewage sludge and succulent tissue of green plants using an accelerator. Int $J$ Nov Res Eng Sci 3(1):62-72

Forste JB (1997) Biosolids processing, products, and uses. In: Rechcigl J (ed) Agricultural uses of by-products and wastes.
ACS Symposium Series, American Chemical Society, Washington, pp 50-61

Fytili D, Zabaniotou A (2008) Utilization of sewage sludge in EU application of old and new methods-a review. Renew Sustain Energy Rev 12:116-140. doi:10.1016/j.rser.2006.05.014

Hassen AI, Bopape FL, Trytsman M (2014) Nodulation study and characterization of rhizobial microsymbionts of forage and pasture legumes. World J Agric Res 2(3):93-100. doi:10.12691/ wjar-2-3-2

Hornick SB, Sikora LJ, Sterrett SB, Murray JJ, Millner PD, Burge WD, Colacicco D, Parr JF, Chaney RL, Willson GB (1984) Utilization of sewage sludge compost as a soil conditioner and fertilizer for plant growth. United States Department of Agriculture, Washington, DC, pp 1-32

Jayne TS, Mather D, Mason N, Ricker-Gilbert J (2013) How do fertilizer subsidy programs affect total fertilizer use in subSaharan Africa? Crowding out, diversion, and benefit/cost assessments. Agric Econ 44:687-703. doi:10.1111/agec.12082

Kofoworola OF (2007) Recovery and recycling practices in municipal solid waste management in Lagos, Nigeria. Waste Manag 27:1139-1143. doi:10.1016/j.wasman.2006.05.006

Kowal NE (1985) Health effects of land application of municipal sludge. U.S. EPA Health Effects Research Laboratory, Research Triangle Park (Pub. No.: EPA/600/1-85/015)

Miyatake F, Iwabuchi K (2006) Effect of compost temperature on oxygen uptake rate, specific rate and enzymatic activity of microorganisms in dairy cattle manure. Bioresour Technol 97:961. doi:10.1016/j.biortech.2005.04.035

Nilsson C, Dahlström H (2005) Treatment and disposal methods for wastewater sludge in the area of Beijing, China. Thesis, Lund University, Sweden

Ogunwole JO, Ogunleye PO (2005) Influence of long-term application of organic and mineral fertilizers on quality of a savanna Alfisol. J Sustain Agric 26:5-14. doi:10.1300/j064v26n0303

Smith KM, Fowler GD, Pullket S, Graham NJD (2009) Sewage sludebased adsorbents: a review of their production, properties and use in water treatment applications. Water Res 43:2569-2594. doi:10.1016/j.watres.2009.02.038

Soumare M, Demeyer A, Tack FMG, Verloo MG (2002) Chemical characteristics of Malian and Belgian solid waste composts. Bioresour Technol 81:97-101. doi:10.1016/S09608524(01)00125-0

Soumare M, Tack FMG, Verloo MG (2003) Characterisation of Malian and Belgian solid waste composts with respect to fertility and suitability for land application. Waste Manag 23:517-522. doi:10.1016/S0956-053X(03)00067-9

Sridhar MKC, Adeoye GO (2003) Organo-mineral fertilizers from urban wastes: developments in Nigeria. Niger Field 68:91-111

Tuomela M, Vikman M, Hatakka A, Itavaara M (2000) Biodegradation of lignin in a compost environment. Bioresour Technol 72:169-183. doi:10.1016/S0960-8524(99)00104-2

U.S. EPA (2017) Biosolids: a short explanation and discussion. In: Biosolids fact sheet project

United State Environmental Protection Agency (2017) Environmental regulations and technology. Control of pathogens and vector attraction in sewage sludge (including domestic septage), Under 40 CFR part 503

Wang M (1997) Land application of sewage sludge in China. Sci Total Environ 197:149-160. doi:10.1016/S0048-9697(97)054260

\section{Publisher's Note}

Springer Nature remains neutral with regard to jurisdictional claims in published maps and institutional affiliations. 